\title{
Effect of Curing Temperature, Activator Solution Composition and Particle Size in Brazilian Fly-Ash Based Geopolymer Production
}

\author{
Adriano Galvão Souza Azevedo ${ }^{*}{ }^{-1,}$ Kurt Strecker ${ }^{a}$, Livia Abreu Barross ${ }^{a}$, Luis Fernando Tonholo ${ }^{a}$, \\ Carolina Torga Lombardi ${ }^{a}$ (C) \\ ${ }^{a}$ Departamento de Engenharia Mecânica (DEMEC), Universidade Federal de São João del-Rei (UFSJ), \\ São João del-Rei, MG, Brasil
}

Received: December 08, 2018; Revised: May 17, 2019; Accepted: June 03, 2019

\begin{abstract}
The geopolymer binder is a relatively new class of inorganic binding material of elevated mechanical strength and good chemical properties. This can be produced using clay minerals or byproducts of the industrial processes, such as metakaolin, fly-ash and blast furnace slag. In this work, geopolymers were produced by alkaline activation of a Brazilian fly-ash with simple and compound solutions $(\mathrm{NaOH}$ and $\mathrm{NaOH}+\mathrm{Na}_{2} \mathrm{SiO}_{3}$ ). The hardened specimens presented values of the mechanical strength close to $48 \mathrm{MPa}$ when the activator used presented $\mathrm{SiO}_{2} / \mathrm{Na}_{2} \mathrm{O}$ ration close to 1.0 after $24 \mathrm{~h}$ of curing at $65^{\circ} \mathrm{C}$. The increase of the temperature to $90{ }^{\circ} \mathrm{C}$ favored the reactions of the N-A-S-H gel (geopolymer) formation and compression strength increased to values close to $90 \mathrm{MPa}$ after $24 \mathrm{~h}$. It has been found that physical properties, such as density and porosity, varied when different $\mathrm{SiO}_{2} / \mathrm{Na}_{2} \mathrm{O}$ rations was present in alkaline solutions. Time, temperature of curing and particle size of fly-ash modified the mechanical and physical proprieties of hardened inorganic binder. Was observed the diffraction phases related to zeolitic phases and carbonate new bands of absorption were related to reactions of $\mathrm{Na} 2 \mathrm{O}$ in excess with atmospheric $\mathrm{CO}_{2}$. The variation of $\mathrm{SiO}_{2} / \mathrm{Na}_{2} \mathrm{O}$ modified the microstructural of the hardened specimens.
\end{abstract}

Keywords: Geopolymers, fly-ash, mechanical activation, mechanical strength.

\section{Introduction}

Worldwide increasing consumption of Ordinary Portland Cement (OPC) increases energy consumption and causes environmental problems by the large quantities of greenhouse gases released during production, mainly $\mathrm{CO}_{2}{ }^{1,3}$. According to Provis and Bernal ${ }^{3}$, concrete is the second-most-used commodity, behind only to water. Therefore, alternative binding materials are being developed which cause less environmental damage and which may be capabale substituing OPC in certain applications of civil construction.

The alkaline activated binding materials, also know as geopolymers or inorganic polymers can be produced by the polycondensation of the $\mathrm{SiO}_{4}$ and $\mathrm{AlO}_{4}$ groups present in aluminosilicate raw materials $\mathrm{s}^{4,5}$. The alkali-activated materials (AAM) can be produced with a wide variety of starting materials rich in silicon and aluminum with short-range atomic ordering ${ }^{6-12}$. Theses amorphous or semi-crystalline compounds are solubilized in an alkaline environment and release monomers promoting the formation of a polymer chain by polycondensation reactions. The polymer chains formed, exhibit three basic structures: the poly (sialate) type, characterized by a -Si-O-Al-O- sequence of atoms, the poly (sialate-siloxo) type, with a-Si-O-Al-O-Si-O- sequence and the poly (sialate - disiloxo) type with a sequence of -Si-OAl-O-Si-O-Si-O-4,13,14. These inorganic compounds can be produced from metakaolin or industrial waste products such

*e-mail: adrianogalvao26@yahoo.com.br as blast furnace slag or fly ash. The production of geopolymers from industrial by-products reduces the final cost and thus increases their market acceptance ${ }^{15,16}$.

Around the world, large quantities of fly-ash are generated every year due to the use of mineral coal in thermoelectric power plants $^{17,18}$. Fly ash has a high concentration of aluminosilicates containing the necessary compounds to produce inorganic binder materials after the geopolymerization reactions. The alkali activation occurs by adding an alkaline solution (sodium or potassium hydroxide and silicate) to fly-ash (FA). The alkaline environment dissolves the amorphous alumina and silica and allows for the silicon and aluminum tetrahedra to form an inorganic compound by sharing oxygen atoms at the vertices ${ }^{2,5}$.

The concentration of the alkaline solution, temperature and curing time and the particle size and composition of the fly-ash are parameters that must be controlled in order to produce high strength inorganic binders ${ }^{1,2,19-21}$. The composition of the fly-ash depends on the initial composition of the coal used to produce energy in the thermal power plant as well as the type of the incinerator and collection filter used in each thermoelectric power plant ${ }^{22}$.

The aim of this work has been to study the production of fly-ash based geopolymers using fly-ash originated from the thermoelectric power plant located at Capivari de Baixo, Santa Catarina, Brazil, as raw material. Furthermore, the influence of the $\mathrm{Na}_{2} \mathrm{O}, \mathrm{H}_{2} \mathrm{O}$ and $\mathrm{Na}_{2} \mathrm{SiO}_{3}$ concentration in the alkaline 
solution, curing temperature and particle size of the fly-ash were investigated in order to observe how the variation of these parameters promote the modification of the properties of the inorganic polymers produced. This investigation is important to promote understanding about the modification in mechanical, physical and chemical proprieties hardened geopolymeric specimens produced by activation of Brasilian fly-ash. The use of different fly ash samples as raw material improves the literature about the production of geopolymers using by products of thermoelectric power station. There is no deeply investigation about the modification in this materiails produced with Brasilian fly ash.

\section{Materials and Methods}

\subsection{Starting materials}

The geopolymeric specimens were produced using fly-ash (FA) from de thermoelectric power plant of Jorge Lacerda located in southern Brazil in Capivari de Baixo, Santa Catarina. The chemical analysis of the Fly-ash classifies this ash as type $\mathrm{F}$, according to ASTM C $618 .{ }^{23}$ This classification is related to the total amount of $\mathrm{SiO}_{2}, \mathrm{Al}_{2} \mathrm{O}_{3}$ and $\mathrm{Fe}_{2} \mathrm{O}_{3}$ being higher than $70 \%$ and the $\mathrm{CaO}$ amount which is less than $10 \%$. The presence of concentrations higher than $10 \%$ of $\mathrm{CaO}$ in the fly ash sample the formation of C-S-H (calcium silicate hydrate) can be observed as reaction product. This is not associated to geopolymeric reaction products. The original fly-ash presented a specific mass close to $2,21 \mathrm{~g} /$ $\mathrm{cm} 3$ with a mean particle size (D50) close to $30.82 \mu \mathrm{m}$, see Figure 1. Furthermore, for the investigation of the influence of particle size on the geopolymerization, the fly ash was drymilled during $24 \mathrm{~h}$. The average particle size (D50) of the FA after milling was $19.7 \mu \mathrm{m}$ and the specific mass $2.38 \mathrm{~g} / \mathrm{cm}^{3}$.

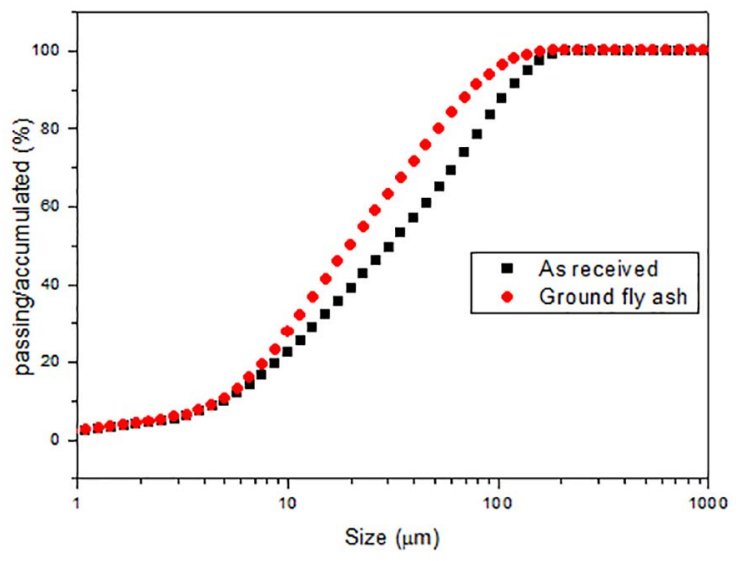

Figure 1. Particle size distribution of the fly ash used.

The $\mathrm{NaOH}$ used to produce the alkaline solutions (activator solutions (AS)) was commercial $\mathrm{NaOH}$ pellets with $98 \%$ purity. The $\mathrm{NaOH}$ was dissolved in deionized water to obtain alkaline solutions with concentrations of
10, 12 and 16 mol. $\mathrm{L}^{-1}$, respectively. The solutions were prepared $24 \mathrm{~h}$ prior to the production of the pastes to ensure cooling of the solutions to room temperature before the FA activation process. Compound solutions were prepared by replacing 10,20 and $30 \mathrm{wt} \%$ of $\mathrm{NaOH}$ by $\mathrm{Na}_{2} \mathrm{SiO}_{3}$ solutions with a water content of $51.4 \mathrm{wt} \%$ and $\mathrm{a} \mathrm{SiO}_{2} / \mathrm{Na}_{2} \mathrm{O}$ molar ratio close to 2.4 .

\subsection{Experimental procedure}

The activation of FA with the alkaline solutions was made using a liquid/solid ratio close to 0.5 . The amount of liquid added to the mixture consists of water present in the $\mathrm{Na}_{2} \mathrm{SiO}_{3}$ and $\mathrm{NaOH}$ solutions and the FA represents the amount of solid material. Table 1 and 2 present the compositions of the mixtures prepared in the different geopolymer materials prepared. To identify the different compositions used to produce the geopolymers the following nomenclature was used. For example, sample H12S20 - 28 represents a specimen produced with a 12 mol.L ${ }^{-1}$ sodium hydroxide solution (H12) with $20 \mathrm{wt} \%$ of sodium silicate and cured for 28 days.

Table 1. Composition of mixtures prepared for the production of geopolymers

\begin{tabular}{lccc}
\hline Mixture & Fly ash $(\mathrm{g})$ & $\begin{array}{c}\mathrm{NaOH} \\
\text { Solution }(\mathrm{g})\end{array}$ & $\begin{array}{c}\mathrm{Na}_{2} \mathrm{SiO}_{3} \text { Solution } \\
(\mathrm{g})\end{array}$ \\
\hline H10S0 & 100 & 50 & 0 \\
H12S0 & 100 & 50 & 0 \\
H16S0 & 100 & 50 & 0 \\
H10S10 & 100 & 40 & 10 \\
H12S10 & 100 & 40 & 10 \\
H16S10 & 100 & 40 & 10 \\
H10S20 & 100 & 30 & 20 \\
H12S20 & 100 & 30 & 20 \\
H16S20 & 100 & 30 & 20 \\
H10S30 & 100 & 20 & 30 \\
H12S30 & 100 & 20 & 30 \\
H16S30 & 100 & 20 & 30 \\
\hline
\end{tabular}

The paste was prpared by mixing the fly-ash and the alkali activator solution in a mechanical mixer. The raw material and the solutions were mixed for 3 minutes at low rotational speed and 2 min at maximum speed. The obtained paste was poured in cylindrical molds with a height and diameter of the 50 and $25 \mathrm{~mm}$, respectively. The specimens were vibrated to ensure compaction and to remove air which may be entrapped. A plastic film was used to cover the cylindrical molds to avoid water loss due to the curing process. After 24 hours at laboratory temperature (close to $25^{\circ} \mathrm{C}$ ), the plastic film was removed and the specimens were cured in an oven for 24 hours at 65 and $90{ }^{\circ} \mathrm{C}$. Thereafter, the specimens were further cured for 1,7 and 28 days at room temperature until the mechanical and microstructural analysis. For each geopolymeric mixture and curing time, 
Table 2. Composition of activator solutions used to produce the alkali-activated specimens

\begin{tabular}{|c|c|c|c|c|c|c|}
\hline \multirow{2}{*}{ Sample } & {$[\mathrm{NaOH}]$} & $\mathrm{Na}_{2} \mathrm{SiO}_{3}$ & $\mathrm{SiO}_{2}$ & $\mathrm{Na}_{2} \mathrm{O}$ & $\mathrm{SiO}_{2} / \mathrm{Na}_{2} \mathrm{O}$ & $\mathrm{H}_{2} \mathrm{O} / \mathrm{FA}$ \\
\hline & mol.L $\mathrm{L}^{-1}$ & [wt-\%] & [wt-\%] & [wt-\%] & [wt-\%] & [wt-\%] \\
\hline H10S0 & 10 & 0 & 0 & 11.70 & 0 & 0.35 \\
\hline $\mathrm{H} 12 \mathrm{~S} 0$ & 12 & 0 & 0 & 13.51 & 0 & 0.33 \\
\hline $\mathrm{H} 16 \mathrm{~S} 0$ & 16 & 0 & 0 & 17.00 & 0 & 0.28 \\
\hline H10S10 & 10 & 10 & 3.36 & 10.80 & 0.31 & 0.33 \\
\hline $\mathrm{H} 12 \mathrm{~S} 10$ & 12 & 10 & 3.36 & 12.31 & 0.27 & 0.31 \\
\hline H16S10 & 16 & 10 & 3.36 & 15.00 & 0.22 & 0.28 \\
\hline H10S20 & 10 & 20 & 6.71 & 10.00 & 0.67 & 0.31 \\
\hline $\mathrm{H} 12 \mathrm{~S} 20$ & 12 & 20 & 6.71 & 11.11 & 0.60 & 0.30 \\
\hline H16S20 & 16 & 20 & 6.71 & 13.20 & 0.51 & 0.27 \\
\hline $\mathrm{H} 10 \mathrm{~S} 30$ & 10 & 30 & 10.07 & 9.20 & 1.10 & 0.29 \\
\hline $\mathrm{H} 12 \mathrm{~S} 30$ & 12 & 30 & 10.07 & 9.90 & 1.02 & 0.28 \\
\hline H16S30 & 16 & 30 & 10.07 & 11.30 & 0.89 & 0.26 \\
\hline
\end{tabular}

10 specimens were prepared. To produce the mechanical activated fly-ash based geopolymers the same procedure was adopted.

The mechanical strength of the hardened specimens was determined using an universal testing machine, Shimadzu model AG-X plus. The crosshead speed during testing was maintained constant at $2 \mathrm{~mm} / \mathrm{min}$ for all samples, according to ASTM C109 ${ }^{17}$. The surface composition and the morphology of the specimens were observed by scanning electron microscopy, SEM. The equipment utilized was a SEM Hitachi model TM 300 with a Spectroscope of Energy Dispersive (EDS), Bruker, model X-Flash SVE. The physical analysis of the hardened specimens were obtained according to the EN ISO $10545-3^{24}$ standard (ISO EN, 1998). X-ray diffraction (Shimadzu model XRD 6000), using $\mathrm{Cu}_{\mathrm{ka}}$ radiation $(\lambda=1,04059 \AA)$ in the $2 \Theta$ range of 5 to $65^{\circ}$ and 30 $\mathrm{Kv}$ and $30 \mathrm{~mA}$, was used to identify the crystalline phases presents in the raw material and the geopolymer materials. Infrared spectroscopy was carried out using a Perkin Elmer Spectrometer, model Spectrum 1000. The analysis was done mixing the milled powder of FA and hardened geopolymers samples with $\mathrm{KBr}(1: 300)$ and compacting pellets thereof in a press (10 ton/60 seconds). The pellets were analyzed in the range of 400 to $4000 \mathrm{~cm}^{-1}$ with a resolution of $4 \mathrm{~cm}^{-1}$.

\section{Results and Discussion}

\subsection{Compressive Strength}

The compressive strength of the fly-ash based geopolymers produced after curing for 1 and 28 days and curing temperatures of 65 and $90{ }^{\circ} \mathrm{C}$ in the first $24 \mathrm{~h}$ are listed in Tables 3 and 4 , respectively.

The results show that the mechanical strength of the geopolymers produced varied widely depending on the
Table 3. Compressive strength of the fly ash based geopolymers cured at $65^{\circ} \mathrm{C}$.

\begin{tabular}{ccc}
\hline \multirow{2}{*}{ Sample } & \multicolumn{2}{c}{ Compressive Strength (MPa) } \\
\cline { 2 - 3 } & 1 Day & 28 Days \\
\hline H10S0 & $4,95 \pm 1,48$ & $9,69 \pm 0,64$ \\
H12S0 & $9,77 \pm 1,56$ & $19,13 \pm 1,06$ \\
H16S0 & $10,17 \pm 1,50$ & $8,77 \pm 1,57$ \\
H10S10 & $32,31 \pm 2,77$ & $34,87 \pm 1,92$ \\
H12S10 & $38,51 \pm 1,49$ & $33,75 \pm 1,19$ \\
H16S10 & $28,05 \pm 0,77$ & $31,96 \pm 2,00$ \\
H10S20 & $23,42 \pm 1,88$ & $33,02 \pm 2,26$ \\
H12S20 & $28,27 \pm 2,67$ & $39,24 \pm 1,55$ \\
H16S20 & $24,60 \pm 1,00$ & $28,96 \pm 0,80$ \\
H10S30 & $19,77 \pm 5,21$ & $28,11 \pm 4,00$ \\
H12S30 & $27,78 \pm 3,65$ & $47,60 \pm 4,50$ \\
H16S30 & $38,87 \pm 3,34$ & $44,25 \pm 1,87$ \\
\hline
\end{tabular}

Table 4. Compressive strength of the fly ash based geopolymers cured at $90^{\circ} \mathrm{C}$.

\begin{tabular}{ccc}
\hline \multirow{2}{*}{ Sample } & \multicolumn{2}{c}{ Compressive Strength $(\mathrm{MPa})$} \\
\cline { 2 - 3 } & 1 Day & 28 Days \\
\hline H10S0 & $13.8 \pm 2.59$ & $18.12 \pm 6.28$ \\
H12S0 & $33.4 \pm 9.21$ & $60.97 \pm 12.69$ \\
H16S0 & $88.5 \pm 8.07$ & $71.07 \pm 9.08$ \\
H10S10 & $31.7 \pm 3.42$ & $27.38 \pm 3.33$ \\
H12S10 & $33.9 \pm 6.24$ & $22.26 \pm 3.72$ \\
H16S10 & $38.8 \pm 3.19$ & $24.63 \pm 4.36$ \\
H10S20 & $35.5 \pm 8.34$ & $40.91 \pm 1.82$ \\
H12S20 & $46.2 \pm 5.05$ & $46.87 \pm 4.65$ \\
H16S20 & $30.2 \pm 5.24$ & $50.88 \pm 5.90$ \\
H10S30 & $46.5 \pm 5.52$ & $58.30 \pm 3.96$ \\
H12S30 & $52.8 \pm 15.07$ & $60.55 \pm 5.22$ \\
H16S30 & $38.6 \pm 11.29$ & $39.65 \pm 10.00$ \\
\hline
\end{tabular}


composition of the activator solutions and the curing temperature. The specimens made using simple activator solutions only with $\mathrm{NaOH}$ present lower mechanical strength for a curing temperature of $65^{\circ} \mathrm{C}$. Samples activated using the $12 \mathrm{~mol} . \mathrm{L}^{-1} \mathrm{NaOH}$ solution exhibited an increase of mechanical strength after 28 days curing from initially 9.8 to $19.1 \mathrm{MPa}$, indicating that polymerization reactions continue to occur after the thermal cure. The sample H16S0 showed a compressive strength close to $10 \mathrm{MPa}$ after $24 \mathrm{~h}$ of curing at $65^{\circ} \mathrm{C}$. However, strength decreased to 8.8 MPa after 28 days which is related to an excessive alkali concentration in the system in the higher concentrated $\mathrm{NaOH}$ solution. The excess of alkali may decrease the mechanical strength of the specimens by the deterioration of the aluminosilicate gel, N-A-S-H $(\mathrm{N}=$ $\mathrm{Na}_{2} \mathrm{O}, \mathrm{A}=\mathrm{Al}_{2} \mathrm{O}_{3}, \mathrm{~S}=\mathrm{SiO}_{2}, \mathrm{H}=\mathrm{H}_{2} \mathrm{O}$ ), that confers compressive strength to the material ${ }^{25,26}$.

Samples produced using compound solutions $(\mathrm{NaOH}+$ $\mathrm{Na}_{2} \mathrm{SiO}_{3}$ ) showed an increase in the compression strength during curing between 1 and 28 days. The specimens produced with 10 wt- $\%$ of $\mathrm{Na}_{2} \mathrm{SiO}_{3}$ presented an increase of the mechanical strength near to $500 \%$ when a $10 \mathrm{M} \mathrm{NaOH}$ solution was used and the temperature of thermal cure was $65^{\circ} \mathrm{C}$. This increase in the mechanical strength of the geopolymers can be observed in all specimens produced with compound solutions. The mechanical strength is higher when 12 or $16 \mathrm{M}$ of $\mathrm{NaOH}$ solutions and 20 or $30 \mathrm{wt}-\%$ of sodium silicate were used to activate the FA. The specimens H12S30 and H16S30 exhibited a mechanical resistance of 47.6 and $44.2 \mathrm{MPa}$, respectively. These results are associated to an increase of $\mathrm{SiO}_{2}$ groups able to react and form the polymer chain. Concomitantly, the increasing $\mathrm{NaOH}$ concentration promotes a better dissolution of the aluminosilicate present in the FA. This in turn provides higher quantities of species to form the N-A-S-H gel structure by polycondensation and increases the mechanical strength of the specimens. However, it is clear that the increase of $\mathrm{NaOH}$ concentrations is not the only factor responsible for the increase of compressive strength. The $\mathrm{Na}_{2} \mathrm{O} / \mathrm{SiO}_{2}$ ratio, as presented in Table 2, is another important variable to be controlled during the activation of FA. The highest compression strength was obtained for samples with a $\mathrm{Na}_{2} \mathrm{O} / \mathrm{SiO}_{2}$ ratio close to 1.0 (H12S30-28), as presented in Figure 2.

When the simple activator was used to produce the pastes and curing at $90^{\circ} \mathrm{C}$, the specimens presented an increase in the compression strength. The samples H10S0, H12S0 and $\mathrm{H} 16 \mathrm{~S} 0$ showed values of compression strength close to 18.1, 61.0, and 71.0 $\mathrm{MPa}$, after 28 days, respectively. A decrease in the mechanical strength was observed in the samples activated with the 16 mol.L $\mathrm{L}^{-1} \mathrm{NaOH}$ solution after 28 days. This may be associated with an excess of $\mathrm{OH}^{-}$ions during the geopolymerization. It has observed that the increase of the curing temperature in the first $24 \mathrm{~h}$ promoted an increase in strength close to $700 \%$, for the H16S0 samples. The increase of the mechanical strength can be related, according to Atis, et al. (2015), to the modification of the boiling point of the $\mathrm{NaOH}$ solution. The boiling point increases with the

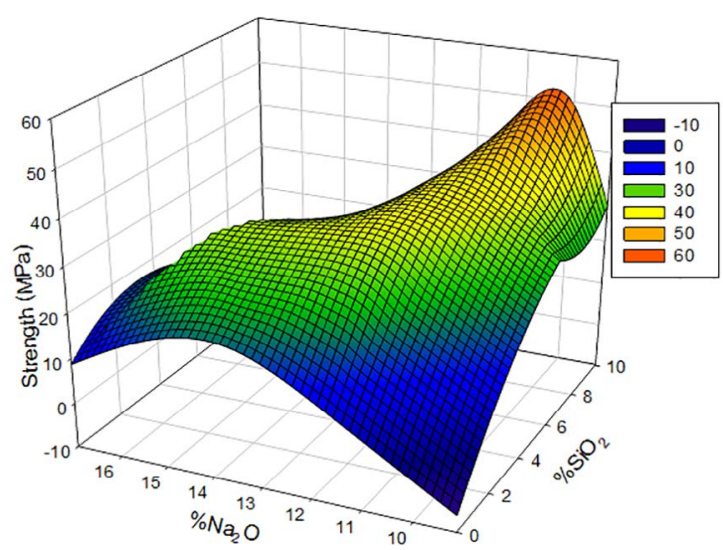

Figure 2. Influence of the $\mathrm{Na}_{2} \mathrm{O}$ and $\mathrm{SiO}_{2}$ concentrations of the alkaline activator solutions on the mechanical strength of the inorganic polymers specimens cured at $65^{\circ} \mathrm{C}$ after 28 days.

increasing $\mathrm{NaOH}$ concentration of the solution. The H16S0 samples were prepared with the solution of highest $\mathrm{NaOH}$ concentration (close to $17 \%$ wt of $\mathrm{Na}_{2} \mathrm{O}$ ). This increase in the boiling point suppresses the evaporation of water present and allows more time to dissolve silica of the fly-ash and promotes a higher amount of N-A-S-H gel formed, that is responsible for the mechanical strength of the geopolymers ${ }^{27}$.

The cured samples produced with compound solutions and cured at $90^{\circ} \mathrm{C}$ presented an increase in the compression strength as also observed in samples cured at $65^{\circ} \mathrm{C}$. Similarly to the samples cured at $65^{\circ} \mathrm{C}$, higher mechanical strength was obtained when the $\mathrm{Na}_{2} \mathrm{O} / \mathrm{SiO}_{2}$ ratio of the mixtures was close to 1.0. This results shows that the geopolymerization reactions were accelerated by a higher curing temperature. These results are presented in Figure 3. These results show that higher mechanical strength of the geopolymers may be obtained by using additional $\mathrm{SiO}_{2}\left(\mathrm{Na}_{2} \mathrm{O} / \mathrm{SiO}_{2}=1.0\right)$ at lower curing temperatures or by the use of compound solutions and highly concentrated $\mathrm{Na}_{2} \mathrm{O}$ solutions which promotes changes in the boiling point of the alkaline solution and accelerates the geopolymerization reactions at a higher temperature of $90^{\circ} \mathrm{C}$.

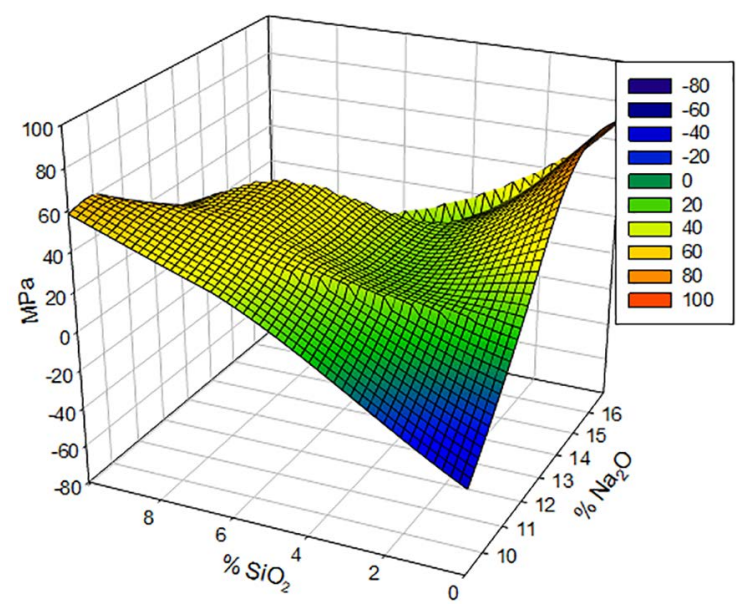

Figure 3. Influence of the $\mathrm{Na}_{2} \mathrm{O}$ and $\mathrm{SiO}_{2}$ concentrations of the alkaline activator solutions on the mechanical strength of the inorganic polymers specimens cured at $90{ }^{\circ} \mathrm{C}$ after 28 days. 


\subsection{Water absorption, apparent porosity and density}

The results of water absorption, apparent porosity and density of the cured specimens after 28 days are presented in Table 5 and 6 . As can be seen from Table 6 , the specimens cured at $65{ }^{\circ} \mathrm{C}$ exhibited a higher apparent porosity when simple activator solutions were used to produce the geopolymers. The increase of $\mathrm{Na}_{2} \mathrm{O}$ concentration promoted a decrease of water absorption and porosity. Employing solutions composed of $\mathrm{NaOH}$ and $\mathrm{Na}_{2} \mathrm{SiO}_{3}$, water absorption diminished in comparison to specimens prepared with $16 \mathrm{M}$ $\mathrm{NaOH}$ solutions. These results are related to a more effective dissolution of the vitreous phases with increasing $\mathrm{Na}_{2} \mathrm{O}$ $\mathrm{Na}_{2} \mathrm{SiO}_{3}$ concentrations forming an aluminosilicate gel that promotes the formation of denser structures, consistent with the microstructures observed by SEM analysis.

When the temperature of curing was increased to $90^{\circ} \mathrm{C}$, the samples presented lower water absorption and a decrease in the apparent porosity. The density of fly ash based geopolymers cured at $90^{\circ} \mathrm{C}$ was more homogeneous thanthat of specimens cured at $65^{\circ} \mathrm{C}$. This can be related to a more effective formation of the N-A-S-H gel promoting a structure with less porosity and lower water absorption. The apparent porosity of the specimens made using the simple activator solutions increased with increasing $\mathrm{NaOH}$ concentration in the activator solutions. This can be related to a decrease in the water amount present in the different alkaline solutions. When $\mathrm{Na}_{2} \mathrm{SiO}_{3}$ was used in the activation, the total porosity presented a decrease for the H10S10 and H10S20 samples. However, samples prepared with 11.3 of $\mathrm{Na}_{2} \mathrm{O}$ and $30 \mathrm{wt}-\%$ of $\mathrm{Na}_{2} \mathrm{SiO}_{3}, \mathrm{H} 16 \mathrm{~S} 30-28$, showed a porosity decrease of nearly $97 \%$ when compared to samples produced with H16S20 activator solution. Increasing the water content of the system results in higher porosity after curing. In this way, substituting $30 \%$ of the $\mathrm{NaOH}$ solution by $\mathrm{Na}_{2} \mathrm{SiO}_{3}$ leads to a decrease of the overall water content of the system and, thus, results in lower porosity.

Table 5. Water absorption, apparent porosity and density of the alkali-activated samples cured at $65^{\circ} \mathrm{C}$ after 28 days.

\begin{tabular}{ccccc}
\hline \multirow{2}{*}{ Sample/65 ${ }^{\circ} \mathrm{C}$} & $\mathrm{Na}_{2} \mathrm{O}$ & Water absorption & Apparent porosity & Density \\
\cline { 2 - 5 } & $(\mathrm{wt}-\% \mathrm{t})$ & $(\%)$ & $(\%)$ & 30.97 \\
\hline H10S0-28 & 11.69 & 20.51 & 24.03 & 1.51 \\
H12S0-28 & 13.51 & 15.36 & 17.80 & 2.06 \\
H16S0-28 & 16.98 & 10.86 & 30.05 & 1.64 \\
H10S10-28 & 10.85 & 20.42 & 27.21 & 2.07 \\
H12S10-28 & 12.31 & 18.03 & 18.87 & 1.66 \\
H16S10-28 & 15.08 & 11.37 & 19.60 & 1.60 \\
H10S20-28 & 10.01 & 12.23 & 25.56 & 2.14 \\
H12S20-28 & 11.11 & 16.08 & 13.41 & 1.88 \\
H16S20-28 & 13.18 & 11.81 & 39.20 & 1.46 \\
H10S30-28 & 9.17 & 26.93 & 20.05 & 2.04 \\
H12S30-28 & 9.90 & 12.28 & 11.93 & 1.86 \\
\hline
\end{tabular}

Table 6. Water absorption, apparent porosity and density of the alkali-activated samples cured at $90{ }^{\circ} \mathrm{C}$ after 28 days.

\begin{tabular}{ccccc}
\hline \multirow{2}{*}{ Sample $/ 90{ }^{\circ} \mathrm{C}$} & $\mathrm{Na} 2 \mathrm{O}$ & Water absorption & Apparently porosity & Density \\
\cline { 2 - 5 } & $(\% \mathrm{wt})^{*}$ & $(\%)$ & $(\%)$ & 1,61 \\
\hline H10S0-28 & 11.69 & 10,22 & 16,40 & 1,62 \\
H12S0-28 & 13.51 & 11,49 & 18,60 & 1,62 \\
H16S0-28 & 16.98 & 12,38 & 20,01 & 1,64 \\
H10S10-28 & 10.85 & 7,49 & 12,28 & 1,61 \\
H12S10-28 & 12.31 & 10,38 & 16,74 & 1,67 \\
H16S10-28 & 15.08 & 9,13 & 15,29 & 1,53 \\
H10S20-28 & 10.01 & 9,15 & 13,98 & 1,52 \\
H12S20-28 & 11.11 & 10,48 & 15,93 & 1,64 \\
H16S20-28 & 13.18 & 11,02 & 18,03 & 1,57 \\
H10S30-28 & 9.17 & 15,92 & 24,99 & 1,64 \\
H12S30-28 & 9.90 & 11,64 & 19,03 & 1,84 \\
\hline
\end{tabular}




\subsection{Phase analysis}

X-ray diffraction patterns of the fly-ash and some of the geopolymers samples produced with different alkaline solutions and cured at 65 and $90{ }^{\circ} \mathrm{C}$ are showed in Figure 4 and 5, respectively. The crystalline phases identified in the fly-ash are quartz ( $\mathrm{SiO}_{2}$ ) (JPDS 01-085-0798), mullite $\left(\mathrm{Al}_{6} \mathrm{Si}_{2} \mathrm{O}_{13}\right)$ (JPDS 01-079-1276) and hematite $\left(\mathrm{Fe}_{2} \mathrm{O}_{3}\right)$ (JPDS 01-086-0550). Furthermore, a broad halo observed between 18 and $35^{\circ}$ indicates the presence of amorphous material that is solubilized after contact with $\mathrm{AS}$ and promotes the production of the N-A-S-H gel. This new amorphous structure formed can be observed by the slightly shifted broad halo to higher $2 \Theta$ angles, between 22 and $40^{\circ}$. This displacement is characteristic for the geopolymerization process and occurred in all samples cured at 65 or $90^{\circ} \mathrm{C}{ }^{28,30}$.

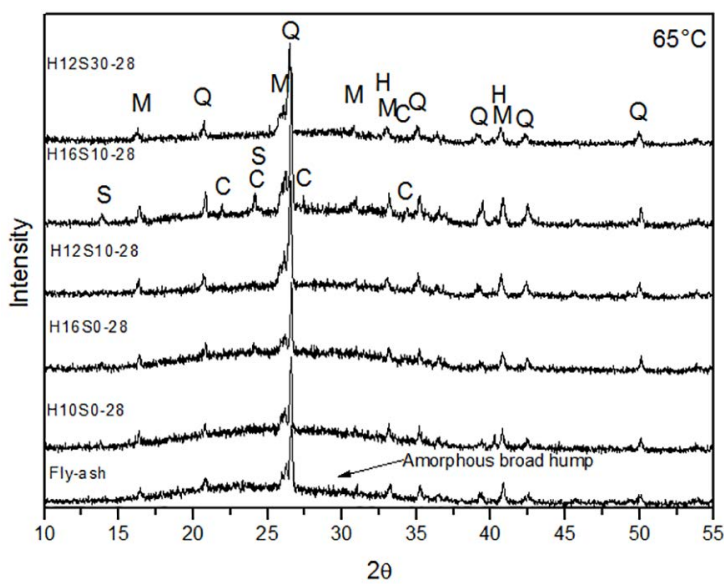

Figure 4. XRD patterns of the original fly ash and alkali activated materials using different activators solutions and cured at $65^{\circ} \mathrm{C}$ after 28 days. Q - Quartz $\left(\mathrm{SiO}_{2}\right), \mathrm{M}-$ Mullite $\left(\mathrm{Al}_{6} \mathrm{Si}_{2} \mathrm{O}_{13}\right), \mathrm{H}$ - Hematite $\left(\mathrm{Fe}_{2} \mathrm{O}_{3}\right), \mathrm{C}$ - Na Chabazite $\left(\mathrm{NaAlSi}_{2} \mathrm{O}_{6} \cdot 3 \mathrm{H}_{2} \mathrm{O}\right)$ and $\mathrm{S}$ - Sodalite $\left(\mathrm{Na}_{4} \mathrm{Al}_{3} \mathrm{Si}_{3} \mathrm{O}_{12} \mathrm{OH}\right)$.

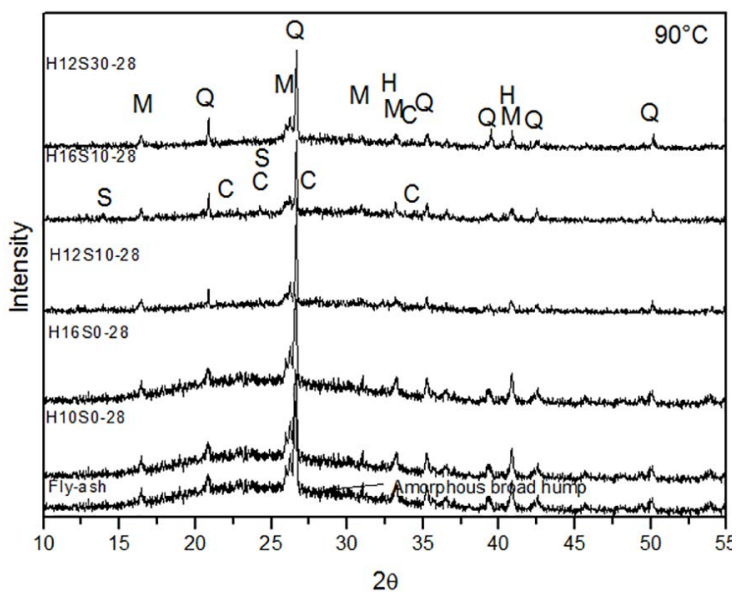

Figure 5. XRD patterns of the original fly ash and alkali activated materials using different activators solutions and cured at $90^{\circ} \mathrm{C}$ after 28 days. Q - Quartz $\left(\mathrm{SiO}_{2}\right)$, M- Mullite $\left(\mathrm{Al}_{6} \mathrm{Si}_{2} \mathrm{O}_{13}\right), \mathrm{H}$ - Hematite $\left(\mathrm{Fe}_{2} \mathrm{O}_{3}\right)$, $\mathrm{C}$ - Na Chabazite ( $\left.\mathrm{NaAlSi}_{2} \mathrm{O}_{6} .3 \mathrm{H}_{2} \mathrm{O}\right)$ and S-Sodalite $\left(\mathrm{Na}_{4} \mathrm{Al}_{3} \mathrm{Si}_{3} \mathrm{O}_{12} \mathrm{OH}\right)$.
The crystal phases found in the original fly-ash are also observed in the geopolymers samples. The presence of these phases is due to the lower dissolution rate of these compounds and therefore do not participate in the reactions forming the inorganic polymer binder. The diffraction patterns of the geopolymers cured at 65 and $90{ }^{\circ} \mathrm{C}$ presented some new phases that are related to zeolite phases found in the artificial synthesis of zeolites. These diffraction peaks of zeolite precursor phases are observed in the fly-ash based binder samples, such as Na-Chabazite $\left(\mathrm{NaAlSi}_{2} \mathrm{O}_{6} \cdot 3 \mathrm{H}_{2} \mathrm{O}\right)$ (JPDS 19-1178) and Sodalite, $\left(\mathrm{Na}_{4} \mathrm{Al}_{3} \mathrm{Si}_{3} \mathrm{O}_{12} \mathrm{OH}\right)$ (JPDS 11 0401). Similar observations were reported by Criado et al. 29 . The increase in the curing temperature does not promote a decrease in the crystalline phases and in the formation of zeolite precursors. The Na-Chabazites were observed in all samples produced with different alkaline activator solutions. However, Sodalite is observed only in the samples produced with high $\mathrm{Na}_{2} \mathrm{O}$ concentrations, see Table 2, H16S0 - 17 wt- $\% \mathrm{Na}_{2} \mathrm{O}$ and $\mathrm{H} 16 \mathrm{~S} 10-15$ wt- $\%$ of $\mathrm{Na}_{2} \mathrm{O}$. This can be related to the excess $\mathrm{Na}_{2} \mathrm{O}$ present in these mixtures that can promote the Sodalite crystallization as observed in the hardened fly-ash based geopolymers after 28 days.

\subsection{Infrared spectroscopy}

The infrared spectra of the FA and some hardened geopolymeric samples cured at 65 and $90{ }^{\circ} \mathrm{C}$ after 28 days are presented in Figure 6 and Figure. 7, respectively. The bands at wavenumbers close to 3600 and $1640 \mathrm{~cm}^{-1}$ are due to the stretching and deformation of $\mathrm{H}-\mathrm{O}-\mathrm{H}$ and $\mathrm{O}-\mathrm{H}$ groups, respectively. These bands are related to water molecules weakly bounded at the surface of geopolymer samples or trapped in the cavities of the hardened inorganic polymers ${ }^{31}$. The bands near to 550 and $770 \mathrm{~cm}^{-1}$ are also observed, which correspond to Mullite, $2 \mathrm{Al}_{2} \mathrm{O}_{3} \cdot \mathrm{SiO}_{2}$, and Quartz, $\mathrm{SiO}_{2}$, as confirmed by XRD analysis, see Figure 4 and 5 . Bands at 1090 and $458 \mathrm{~cm}^{-1}$ are associated with the stretching and bending of Si-O or Al-O bands, respectively ${ }^{21}$.

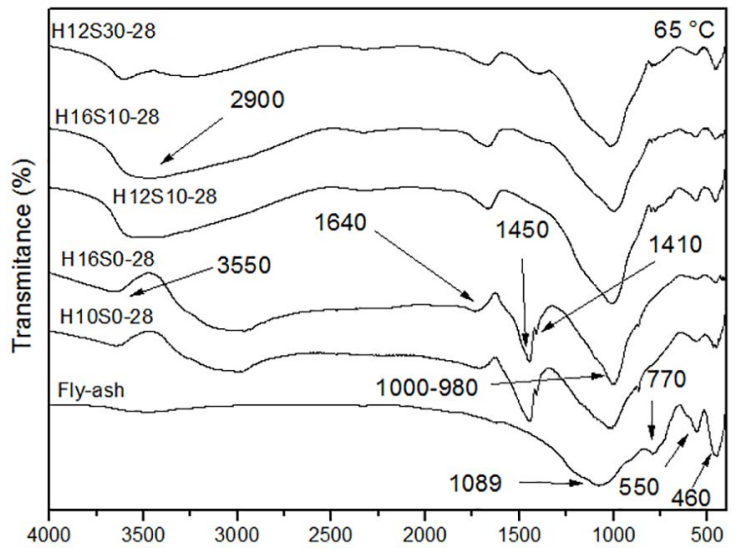

Figure 6. FTIR spectra of geopolimeric samples cured at $65{ }^{\circ} \mathrm{C}$ after 28 days prepared with different activators solutions. 


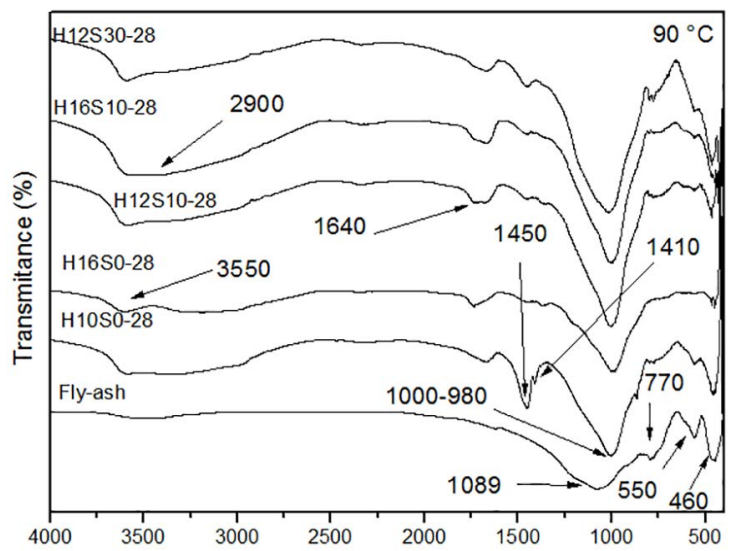

Figure 7. FTIR spectra of geopolimeric samples cured at $90{ }^{\circ} \mathrm{C}$ and after 28 days prepared with different activators solutions.

The band present in the original fly ash at wavenumber close to $1089 \mathrm{~cm}^{-1}$ is shifted to lower frequencies, $1000-980$ $\mathrm{cm}^{-1}$, after the contact of the FA with the activator solutions. This shift is attributed to the formation of an aluminosilicate gel and the formation of a tridimensional framework involving silicon and aluminum tetrahedra. During the geopolymeric reactions, the glassy component present in the fly-ash reacts with the alkaline solutions and forms N-A-S-H, an aluminosilicate gel. The amount of $\mathrm{SiO}_{2}$ and $\mathrm{Na}_{2} \mathrm{O}$ present in the system during the reactions promotes the shift of the band to higher or lower wavenumbers, due to the effectiveness of each activator solution to dissolve and to form the polymeric chains. The shift of the band corresponding to asymmetric vibrations generated by T-O-T ( $\mathrm{T}$ is $\mathrm{Si}$ or $\mathrm{Al}$ ) to lower wavenumber can be associated to the replacement of $\mathrm{Si}^{4+}$ by $\mathrm{Al}^{3+}$ that occurs during the geopolymer production. The formation of Al-O bonds in the inorganic polymer product modifies the signal to lower frequencies because the Al-O bond is longer than the Si-O bond. In other words, the observation of T-O-T at a lower wavenumber can be used to prove the formation of the new structure. This newly formed structure (N-A-S-H gel) is responsible for an increase in the mechanical strength and the formation of a material with cementitious proprieties $^{1,32}$.

The increase of curing temperature promoted some changes in the infrared spectrum of the inorganic binder after 28 days, see Figure 7 . Is possible to verify the presence of an intense band at $1450 \mathrm{~cm}^{-1}$ in the spectrum of H16S0 cured at $65^{\circ} \mathrm{C}$, which is attributed to the reaction of $\mathrm{Na}_{2} \mathrm{O}$ in excess with atmospheric $\mathrm{CO}_{2}$, according to Eq. 1 .

$$
2 \mathrm{NaOH}+\mathrm{CO}_{2} \rightarrow \mathrm{Na}_{2} \mathrm{CO}_{3}+\mathrm{H}_{2} \mathrm{O}
$$

The bands at 1450 and $1410 \mathrm{~cm}^{-1}$ can be attributed to sodium carbonate, and the crystallization of $\mathrm{Na}_{3} \mathrm{H}\left(\mathrm{CO}_{3}\right)_{2} \cdot 2 \mathrm{H}_{2} \mathrm{O}$ may occur as efflorescence in fly-ash based inorganic polymers. These compounds observed in the FTIR analysis are not observed by the XRD analysis because their concentration is below the detection limit of the XRD apparatus or the amorphous aluminosilicate gel formed on the surface may prevent the detection of such phases The band at $2900 \mathrm{~cm}^{-1}$ is attributed to the $\mathrm{C}-\mathrm{H}$ vibration present in the $\mathrm{Na}_{3} \mathrm{H}\left(\mathrm{CO}_{3}\right)_{2} \cdot 2 \mathrm{H}_{2} \mathrm{O}$ compound. The samples $\mathrm{H} 16 \mathrm{~S} 0$ cured at $90^{\circ} \mathrm{C}$ did not present a band close to $1450 \mathrm{~cm}^{-1}$ related to $\mathrm{Na}_{2} \mathrm{CO}_{3}^{7,33-35}$. This can be associated with a higher effectiveness to form the gel N-A$\mathrm{S}-\mathrm{H}$ gel of this system when the high $\mathrm{Na}_{2} \mathrm{O}$ concentration is used and the specimens are cured at $90^{\circ} \mathrm{C}$ in the first $24 \mathrm{~h}$, as previously discussed. The bands related to carbonated products present a lower intensity when $\mathrm{Na}_{2} \mathrm{SiO}_{3}$ is used in the alkaline solution. This can be associated with a higher effectiveness of dissolving and forming the tridimensional framework gel (N-A-S-H) consuming the alkaline species present in the solution and preventing the formation of carbonation products.

\subsection{Microstructural analysis}

SEM images of the fly-ash and the inorganic polymers samples produced are presented in Figure 8. The FA is composed of spherical particles of different sizes. This result is consistent with the analysis of the particle size presented in Figure. 1. The contact of the FA with different alkaline solutions promotes the dissolution of the fly-ash particles and the formation of a $\mathrm{Si}$ and $\mathrm{Al}$ rich aluminosilicate gel that presents a morphology more densified and compacted. The presence of surface cracks can be observed in samples produced with a low amount of water and high sodium silicate percentages. This can be related to the low workability of this mixture and the difficulty to accommodate the paste in the cylindrical molds.

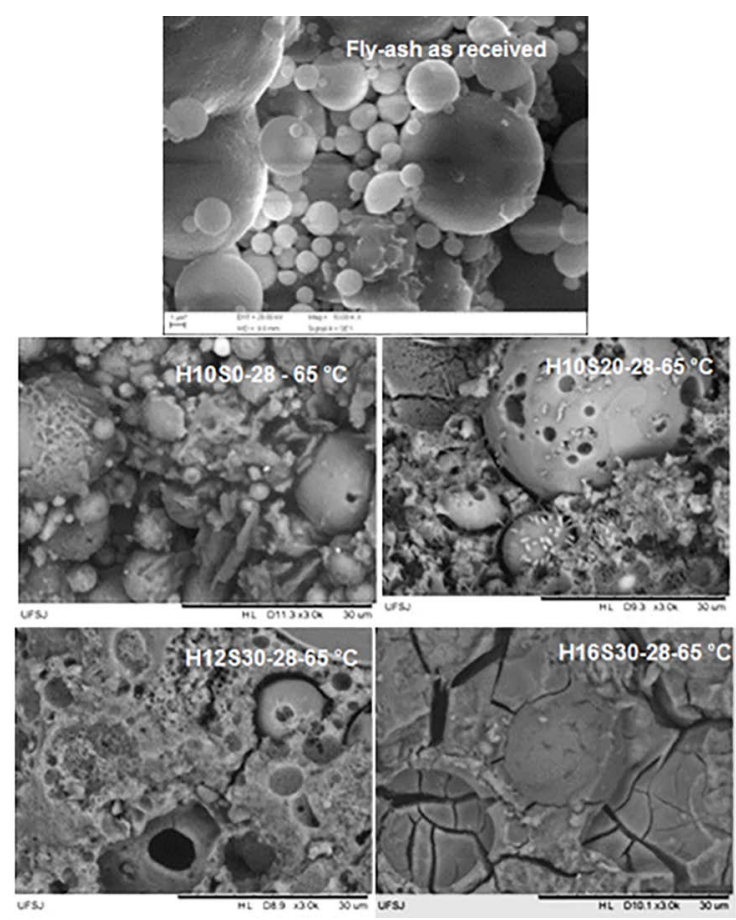

Figure 8. SEM images of the fly-ash and fly-ash based geopolymers produced with different activator alkaline solutions, cured at $65^{\circ} \mathrm{C}$ after 28 days. 
Furthermore, it is possible to observe that some spherical particles of the original fly-ash powder are still intact after the contact with the alkaline solutions, which is associated to the lower effectiveness of these solutions to dissolve all particles. This result can be associated with the lower effective dissolution by the alkaline activators. An increase of the dissolution rate can be obtained by increasing $\mathrm{Na}_{2} \mathrm{O}$ $\mathrm{Na}_{2} \mathrm{SiO}_{3}$ concentrations that promote the formation of a higher amount of N-A-S-H gel, increasing the mechanical strength. The surfaces of cured samples prepared with compound solutions present a lower concentration of fly-ash particles without reacting. This corroborates with results about the increase of dissolution and $\mathrm{N}-\mathrm{A}-\mathrm{S}-\mathrm{H}$ gel formation when $\mathrm{Na}_{2} \mathrm{SiO}_{3}$ is used during the geopolymerization reactions.

When the specimens were cured at $90^{\circ} \mathrm{C}$, the morphology of the inorganic polymers presented few FA particles on the surface. The images are showed in Figure 9. The sample H16S0 presented the highest mechanical strength of samples cured at $90^{\circ} \mathrm{C}$. The surface morphology of this material did not present unreacted fly-ash particles. This can be associated with the high $\mathrm{Na}_{2} \mathrm{O}$ amount present in this activator solution promoting the release of $\mathrm{Si}$ and $\mathrm{Al}$ rich specimens to the system and contributing to the formation of a high amount of N-A-S-H gel ${ }^{2}$.
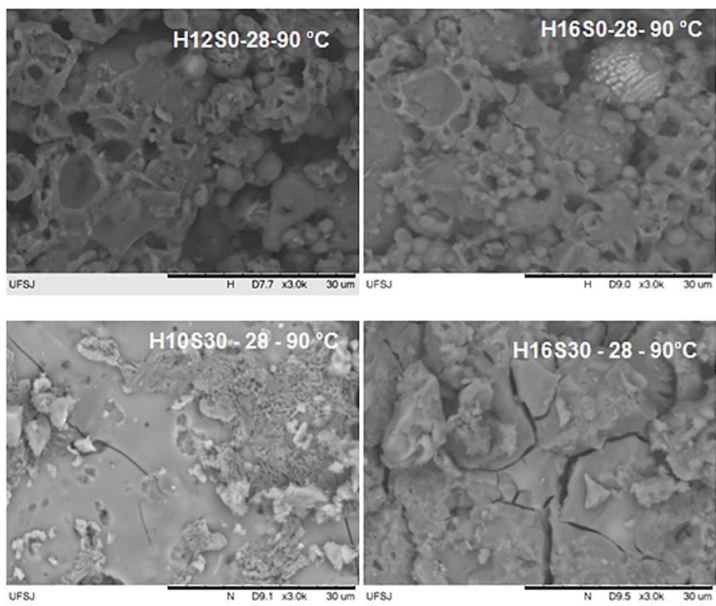

Figure 9. SEM images of the fly-ash and fly-ash based geopolymers produced with different activator alkaline solutions, cured at $90{ }^{\circ} \mathrm{C}$ after 28 days.

The sample $\mathrm{H} 16 \mathrm{~S} 30$ cured at $90^{\circ} \mathrm{C}$ presents more cracks on the surface when compared to the samples cured at 65 ${ }^{\circ} \mathrm{C}$. Their presence may cause the decrease in the mechanical strength as observed previously.

\subsection{Mechanical activation of the Brazilian fly-ash}

The mechanical activation of fly-ash by milling was conducted in order to promote a decrease in particle size. According to Hounsi et al. ${ }^{33,36}$, the decrease of particle size is related to an increase of the surface and, consequently, an increase of the contact area of the FA particles with the activator solutions. This promotes particle dissolution and the release of $\mathrm{Si}$ and $\mathrm{Al}$ rich species to the system, increasing the formation of the N-A-S-H gel. The specimens were produced following the steps described in the production of geopolymers synthesized with fly ash as-received. Some of the conditions were studied in the mechanical activation, as presented in Table 7.

\subsection{Mechanical proprieties}

The mechanical strength of the geopolymers produced after milling of the FA and cured for 1, 7 and 28 days are listed in Table 8.

The mechanical activation of the fly-ash by dry milling promoted an increase of the mechanical strength of samples cured at $65^{\circ} \mathrm{C}$. On the other hand, samples cured at $90{ }^{\circ} \mathrm{C}$, which showed the highest compression resistance when produced with as received fly-ash, exhibited inferior resistance after milling of the FA original powder. The samples H12S0 and $\mathrm{H} 16 \mathrm{~S} 0$ cured at $65^{\circ} \mathrm{C}$ and produced with the original $\mathrm{FA}$ showed an increase in resistance close to 50 and $200 \%$ after 28 days of cure when mechanical activation by milling was used. This can be related to the increase of surface area by milling, promoting an increased contact area of the alkaline solution with the raw material and promoting the dissolution and the release of more $\mathrm{Si}$ and $\mathrm{Al}$ rich specimens able to form N-A-S-H gel. However, the decrease of particle size of the FA was not beneficial for specimens cured at $90{ }^{\circ} \mathrm{C}$ in the firsts 24 hours. The mechanical activation of FA resulted in a decrease of almost all geopolymers samples cured at 90 ${ }^{\circ} \mathrm{C}$ and for all curing times. A decrease in the mechanical strength of the samples produced with simple solutions was associated with $\mathrm{OH}^{-}$ion excess present in these systems after 28 days of cure. This result was observed in the samples produced with the original fly-ash and cured at 65 and $90{ }^{\circ} \mathrm{C}$. Samples produced with $\mathrm{H} 12 \mathrm{~S} 20$ and H12S30 solutions presented an increase close to 15 and $5.5 \%$, respectively. These results show that the mechanical activation promoted an improvement of the resistance in samples produced without the presence of $\mathrm{Na}_{2} \mathrm{SiO}_{3}$ solutions.

\subsection{Water absorption, apparent porosity and density}

The values of physical analysis of the fly-ash base geopolymers prepared with milled powders after 28 days of curing are presented in Table 9. The mechanical activation promoted a decrease of density of specimens cured at $65^{\circ} \mathrm{C}$. For example, samples H12S0 and H12S20 prepared with as-received fly ash powder, presented a density of 2.02 and $2.06 \mathrm{~g} / \mathrm{cm}^{3}$, respectively, the corresponding samples prepared with milled powders exhibited a decrease of the density to 1.59 and $1.67 \mathrm{~g} / \mathrm{cm}^{3}$, respectively. The samples cured at $90{ }^{\circ} \mathrm{C}$ did not present major changes related to density, showing that curing at a higher temperature promoted the formation of a more homogenous aluminosilicate matrix after of the 28 days of curing. 
Table 7. Temperature of cure and composition of alkaline solutions used to produce the geopolymers specimens by mechanical activation.

\begin{tabular}{cccccc}
\hline Sample & $\% \mathrm{Na}_{2} \mathrm{O}$ & $\% \mathrm{SiO}_{2}$ & $\mathrm{SiO}_{2} / \mathrm{Na}_{2} \mathrm{O}$ & $\mathrm{H}_{2} \mathrm{O} / \mathrm{CV}_{(\mathrm{wt})}$ & $\begin{array}{c}\text { Temperature of } \\
\text { cure }\left({ }^{\circ} \mathrm{C}\right)\end{array}$ \\
\hline H12S0 - 65 & 13,51 & 0 & 0 & 0,33 & 65 \\
$\mathrm{H} 16 \mathrm{~S} 0-65$ & 16,98 & 0 & 0 & 0,28 & 65 \\
$\mathrm{H} 12 \mathrm{~S} 20-65$ & 11,11 & 6,71 & 0,60 & 0,30 & 65 \\
$\mathrm{H} 12 \mathrm{~S} 30-65$ & 9,90 & 10,07 & 1,02 & 0,28 & 65 \\
$\mathrm{H} 12 \mathrm{~S} 0-90$ & 13,51 & 0 & 0 & 0,33 & 90 \\
H16S0 - 90 & 16,98 & 0 & 0 & 0,28 & 90 \\
H12S20 - 90 & 11,11 & 6,71 & 0,60 & 0,30 & 90 \\
H12S30 - 90 & 9,90 & 10,07 & 1,02 & 0,28 & 90 \\
\hline
\end{tabular}

Table 8. Compressive strength of the fly ash based geopolymers produced with milled powders, cured at 65 and $90{ }^{\circ} \mathrm{C}$.

\begin{tabular}{cccc}
\hline & \multicolumn{3}{c}{ Compressive Strength (MPa) } \\
\hline Sample & 1 Day & 7 Days & 28 Days \\
\hline H12S0 - 65 & $28.31 \pm 1.59$ & $23.97 \pm 2.23$ & $27.81 \pm 2.39$ \\
H16S0 - 65 & $30.55 \pm 2.52$ & $33.61 \pm 2.68$ & $45.17 \pm 3.26$ \\
H12S20 - 65 & $46.00 \pm 3.77$ & $45.43 \pm 2.80$ & $50.25 \pm 8.84$ \\
H12S30 - 65 & $39.45 \pm 8.89$ & $44.03 \pm 8.90$ & $43.68 \pm 2.24$ \\
H12S0 - 90 & $29.20 \pm 3.04$ & $46.57 \pm 7.40$ & $32.84 \pm 4.64$ \\
H16S0 - 90 & $27.58 \pm 2.28$ & $61.31 \pm 9.50$ & $40.38 \pm 10.83$ \\
H12S20 - 90 & $55.04 \pm 7.76$ & $36.85 \pm 7.90$ & $42.71 \pm 8.04$ \\
H12S30 - 90 & $32.55 \pm 4.98$ & $38.10 \pm 1.30$ & \\
\hline
\end{tabular}

Table 9. Water absorption, apparent porosity and density of the alkali-activated samples produced using milled powders and cured at 65 and $90{ }^{\circ} \mathrm{C}$ after 28 days.

\begin{tabular}{ccccc}
\hline Sample & $\mathrm{Na}_{2} \mathrm{O}(\% \mathrm{wt})$ & Water absorption $(\%)$ & Apparently porosity $(\%)$ & Density $\left(\mathrm{g} / \mathrm{cm}^{3}\right)$ \\
\hline H12S0 - 65 & 13.51 & 14,04 & 22,42 & 1,59 \\
H16S0 - 65 & 16.98 & 8,60 & 14,46 & 1,68 \\
H12S20 - 65 & 11.11 & 8,87 & 14,67 & 1,67 \\
H12S30 - 65 & 9.90 & 8,90 & 15,02 & 1,68 \\
H12S0 - 90 & 13.51 & 14,69 & 23,49 & 1,59 \\
H16S0 - 90 & 16.98 & 9,22 & 15,40 & 1,67 \\
H12S20 - 90 & 11.11 & 12,97 & 21,06 & 1,62 \\
H12S30 - 90 & 9.90 & 11,57 & 19,47 & 1,68 \\
\hline
\end{tabular}

The samples H12S20-90 and H12S30-90 (after 28 days) exhibited porosity close to 15.8 and $19.0 \%$, respectively. After mechanical activation, these values increased to 21.12 and $19.65 \%$, respectively, representing an increase close to 25 and $3 \%$. The samples produced with the milled powders, compound solutions and cured at $65^{\circ} \mathrm{C}, \mathrm{H} 12 \mathrm{~S} 20$ and $\mathrm{H} 12 \mathrm{~S} 30$, presented a decrease of the porosity close to 43 and $21 \%$, respectively, after 28 days of cure. These results can be related to the amount of water present in the mixtures. The mechanical activation of the FA destroys the spherical morphology of raw material particles resulting in a decreased workability of the fresh paste and, consequently, difficulting the accommodation into the molds. This may promote the appearance of defect regions related to voids present in the cured specimens. In contrast, the higher curing temperature may promote the acceleration of water evaporation from the system, thus favoring the lower dissolution of the starting material, which can be observed by the decrease in the mechanical properties of geopolymers cured at $90{ }^{\circ} \mathrm{C}$ after mechanical activation.

\subsection{Phase analysis}

X-ray diffraction patterns of some samples produced using milled fly-ash powders are shown in Figure 10. The mechanical activation does not promote an increase of the dissolution of highly ordered phases. This can be confirmed by the presence of diffraction peaks of quartz, mullite and hematite that are observed in the all samples after 28 days 
of cure. The shift of the amorphous halo (18 - $\left.35^{\circ} 2 \theta\right)$ present in the original fly-ash and related to be N-A-S-H gel formation is also observed in the samples produced with milled powders. Zeolitie precursors were also identified in the samples produced with simple and compound alkaline solutions. Furthermore, diffraction peaks related to $\mathrm{Na}-$ Chabazite, and sodalite were observed in the cured samples. The Sodalite peaks were more intense in the samples produced after mechanical activation and solutions with high $\mathrm{Na}_{2} \mathrm{O}$ concentration (H16S0). This can be related to the effectiveness of alkaline solutions when the surface area was increased by the FA particle size decrease after milling. A new phase related to Zeolite $\mathrm{P}\left(\mathrm{Na}_{3,6} \mathrm{Al}_{3,6} \mathrm{Si}_{12,4} \mathrm{O}_{32} .12 \mathrm{H}_{2} \mathrm{O}\right.$ - JCPDS 401464) was observed in the samples H16S0 and H12S30 solutions after curing at $90^{\circ} \mathrm{C}$ in the first $24 \mathrm{~h}$. According to Criado et. al., (2007), the formation of this kind of precursor is related to the higher stability of zeolites, that tend to turn into chabazite and sodalite with increasing curing time ${ }^{29}$.

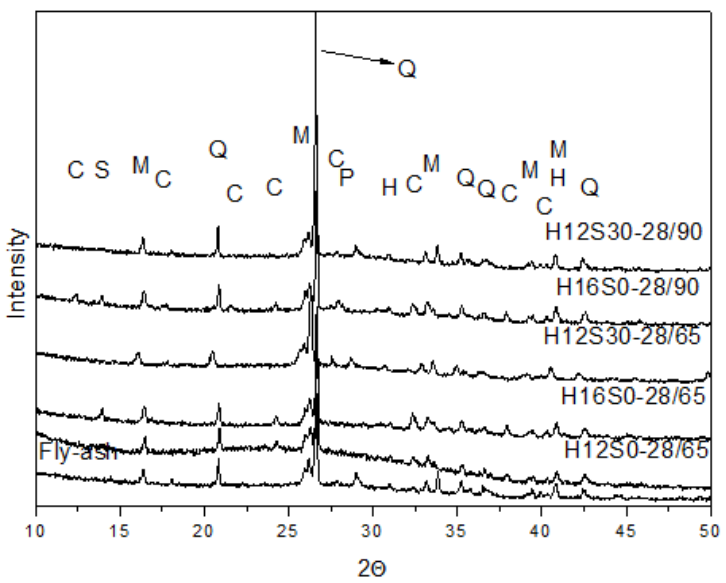

Figure 10. XRD patterns of the original fly ash and alkali activated materials produced with milled powders, cured at 65 and $90^{\circ} \mathrm{C}$ after 28 days. Q - Quartz $\left(\mathrm{SiO}_{2}\right), \mathrm{M}$ - Mullite $\left(\mathrm{Al}_{6} \mathrm{Si}_{2} \mathrm{O}_{13}\right), \mathrm{H}$ - Hematite $\left(\mathrm{Fe}_{2} \mathrm{O}_{3}\right), \mathrm{C}-\mathrm{Na}$ Chabazite $\left(\mathrm{NaAlSi}_{2} \mathrm{O}_{6} \cdot 3 \mathrm{H}_{2} \mathrm{O}\right)$ and $\mathrm{S}$ - Sodalite $\left(\mathrm{Na}_{4} \mathrm{Al}_{3} \mathrm{Si}_{3} \mathrm{O}_{12} \mathrm{OH}\right)$.

\subsection{Infrared spectroscopy}

The infrared spectra of the samples produced with milled FA powders after 28 days are presented in Figure 11. The absorption bands observed in the samples are similar to the bands found in the materials produced with as-received fly-ash. The bands corresponding to the presence of water molecules in the system and present inside the pours or weakly bound on the surface are observed at 3600 and $1650 \mathrm{~cm}^{-1}$. This vibration can be related to the $\mathrm{OH}$ groups presents in silanol formed during the dissolution process ${ }^{4,37}$. The shift in the band at $1080 \mathrm{~cm}^{-1}$ to regions close to $1000 \mathrm{~cm}^{-1}$ still represents the formation of the N-A-S-H gel. This shift was observed in all samples, produced with original and milled FA, showing that the process of polycondensation occurs in all systems.
In the sample $\mathrm{H} 16 \mathrm{~S} 0$ - 28 and cured at $65^{\circ} \mathrm{C}$ an intense band in regions close to $1450 \mathrm{~cm}^{-1}$ has been observed, which is related to the reaction of excess alkali with carbon dioxide from the atmosphere. This increase in the absorption band can be associated to the increasing efficiency of the dissolution of the FA by the alkaline solutions when the surface area of the powder particles was increased by milling. This may promote an increase of the alkali in excess, which is more pronounced in solutions with high $\mathrm{Na}_{2} \mathrm{O}$ concentrations.

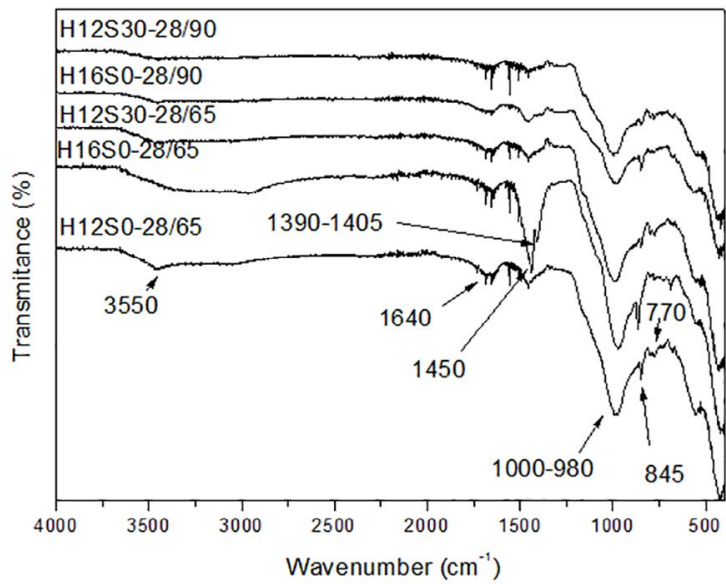

Figure 11. FTIR spectra of geopolymer samples produced milled FA powders, cured at 65 and $90^{\circ} \mathrm{C}$ after 28 days using different activators solutions.

The band near to $2900 \mathrm{~cm}^{-1}$ is related to the formation of carbonated compounds such as $\mathrm{NaHCO}_{3}$ and is associated to $\mathrm{C}-\mathrm{H}$ stretch vibrations. Another modification promoted by the milling of the FA was the presence of the carbonated product of calcium, as verified by the bands at 1400 and $865 \mathrm{~cm}^{-1}$ which are associated to bend vibrations present in the $\mathrm{CO}_{3}^{-2}$ group of $\mathrm{CaCO}_{3}$. According to Cai et.al. ${ }^{38}$, the band at $865 \mathrm{~cm}^{-1}$ indicates the formation of amorphous calcium carbonate on the surface of the specimens. This band was more intense when the simple solution, specifically $16 \mathrm{M} \mathrm{NaOH}$, was used to activate the flyash. The same band presents lower intensity when the samples were prepared with solutions containing $\mathrm{Na}_{2} \mathrm{SiO}_{3}$. The presence of extra $\mathrm{SiO}_{2}$ can promote the increase of N-A-S-H gel formation and, this way, the alkaline metal cations present in the system, $\mathrm{Na}^{+}$and $\mathrm{Ca}^{2+}$, act in neutralizing the negative charges of the $\mathrm{AlO}_{4}^{-}$groups.

\subsection{Microstructural analysis}

The SEM analysis of the cured specimens after 28 days is presented in Figure 12. The mechanical activation promoted the decrease of particle size of the raw material, the spherical particle morphology being broken into small fragments. Samples prepared with as-received FA still present some unreacted spherical particles. Higher curing temperature and the use of highly concentrated $\mathrm{Na}_{2} \mathrm{O}$ solutions increased the dissolution rate and, in consequence, less intact spherical fly ash particles were found in these samples. 


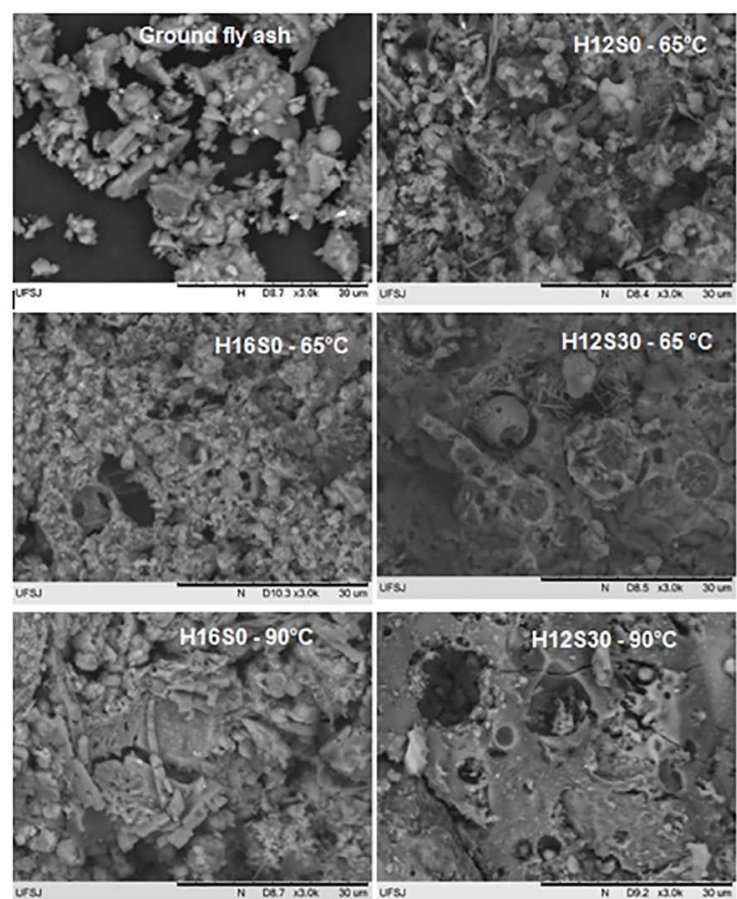

Figure 12. SEM images of the fly-ash after $24 \mathrm{~h}$ of milling and flyash based geopolymers produced with different alkaline activator solutions and milled powders, cured at 65 and $90^{\circ} \mathrm{C}$ after 28 days.

\section{Conclusions}

Based on the results obtained by the mechanical and microstructural analysis of the different fly ash based geopolymers produced with different alkaline solutions the following conclusions can be drawn:

It has been shown that the fly-ash provided by the Brazilian power plant can be used as raw material for the production of inorganic binding materials and may be an alternative to reduce the amount of solid waste in landfills.

The $\mathrm{Na}_{2} \mathrm{O}, \mathrm{Na}_{2} \mathrm{SiO}_{3}$ and $\mathrm{H}_{2} \mathrm{O}$ concentrations of the alkaline activator solutions were the principal factors that influence the final proprieties of the geopolymers. The mechanical strength of the specimens reached values near the maximum in the first 24 hours of curing. It was observed that an excess of $\mathrm{OH}^{-}$ions caused a decrease in the values of mechanical resistance. This excess was controlled by using solutions containing additional $\mathrm{SiO}_{2}$. The use of $\mathrm{Na}_{2} \mathrm{SiO}_{3}$ in the activator solution increases the mechanical strength of the specimens after curing. The maximum resistance was obtained for compound solutions with a $\mathrm{Na}_{2} \mathrm{O} / \mathrm{SiO}_{2}$ ratio close to 1.0 .

The curing temperature used in the first 24 hours influences the geopolymerization reaction and, consequently, the formation of the N-A-S-H gel. Specimens cured at $90{ }^{\circ} \mathrm{C}$ reached higher mechanical strength when compared to identical specimens cured at $65^{\circ} \mathrm{C}$.

The decrease of the FA particle size by milling promoted an improvement in the mechanical and physical properties of the specimens cured at $65^{\circ} \mathrm{C}$. These results showed that the reduction of particle size is related to an increased dissolution rate of the amorphous compounds by the alkaline activator solution. The release of rich $\mathrm{Si}$ and $\mathrm{Al}$ specimens to the system is responsible for the higher mechanical strength observed in these specimens due to the larger amount of $\mathrm{N}-\mathrm{A}-\mathrm{S}-\mathrm{H}$ gel produced during the polymerization reactions.

\section{References}

1. Azevedo AGS, Strecker K. Brazilian fly ash based inorganic polymers production using different alkali activator solutions. Ceramics International. 2017:43(12):9012-9018. DOI: 10.1016/j. ceramint.2017.04.044

2. Azevedo AGS, Strecker K. Influência da Composição Química das Soluções Alcalinas Ativadoras na Produção de Geopolímeros a Base de Cinza Volante. Revista Eletrônica de Materiais e Processos. 2017;12(1):39-46.

3. Provis JL, Bernal SA. Geopolymers and Related Alkali-Activated Materials. Annual Review of Materials Research. 2014;44(2014):299327. DOI: 10.1146/annurev-matsci-070813-113515

4. Davidovits J, Davidovics M. Composite Materials with Geopolymer Matrix. In: Proceedings of Geopolymer '88; 1988 Jun 1-3; Compiègne, France. p. 325-337.

5. Davidovits J. Geopolymeric Reaction in Archeological Cements and in Modern Blended Cements. In: Proceedings of Geopolymer '88; 1988 Jun 1-3; Compiègne, France. p. 93-105.

6. Chen JH, Huang JS, Chang YW. A preliminary study of reservoir sludge as a raw material of inorganic polymers. Construction and Building Materials. 2009;23(10):3264-3269. DOI: 10.1016/j. conbuildmat.2009.05.006

7. Temuujin J, van Riessen A. Effect of fly ash preliminary calcination on the properties of geopolymer. Journal of Hazardous Materials. 2009;164(2-3):634-639. DOI: 10.1016/j.jhazmat.2008.08.065

8 Duxson P, Fernández-Jiménez A, Provis JL, Lukey GC, Palomo A, van Deventer JSJ. Geopolymer technology: the current state of the art. Journal of Materials Science. 2006;42(9):2917-2933. DOI: $10.1007 / \mathrm{s} 10853-006-0637-\mathrm{z}$

9. Majidi B. Geopolymer technology, from fundamentals to advanced applications: a review. Materials Technology Advanced Performance Materials. 2009;24(2):79-87. DOI: $10.1179 / 175355509 X 449355$

10. Belmokhtar N, Ammari M, Brigui J, Ben allal L. Comparison of the microstructure and the compressive strength of two geopolymers derived from Metakaolin and an industrial sludge. Construction and Building Materials. 2017;146:621-629. DOI: 10.1016/j.conbuildmat.2017.04.127

11. Istuque DB, Reig L, Moraes JCB, Akasaki JL, Borrachero MV, Soriano L, et al. Behaviour of metakaolin-based geopolymers incorporating sewage sludge ash (SSA). Materials Letters. 2016;180:192-195. DOI: 10.1016/j.matlet.2016.05.137

12. Jiao X, Zhang Y, Chen T. Thermal stability of a silica-rich vanadium tailing based geopolymer. Construction and Building Materials. 2013;38:43-47. DOI: 10.1016/j.conbuildmat.2012.06.076 
13. Davidovits J. Geopolymer chemistry and properties. In: Proceedings of Geopolymer '88; 1988 Jun 1-3; Compiègne, France. p. 25-48.

14. Davidovits J. Structural Characterization of Geopolymeric Materials with X-Ray Diffractometry and MAS-NMR Spectroscopy. In: Proceedings of Geopolymer '88; 1988 Jun 1-3; Compiègne, France. p. 149-166.

15. Khale D, Chaudhary R. Mechanism of geopolymerization and factors influencing its development: a review. Journal of Materials Science. 2007;42(3):729-746. DOI: 10.1007/s10853006-0401-4

16. McLellan BC, Williams RP, Lay J, van Riessen A, Corder GD. Costs and carbon emissions for geopolymer pastes in comparison to ordinary portland cement. Journal of Cleaner Production. 2011;19(9-10):1080-1090. DOI: 10.1016/j.jclepro.2011.02.010

17. Nath SK, Maitra S, Mukherjee S, Kumar S. Microstructural and morphological evolution of fly ash based geopolymers. Construction and Building Materials. 2016;111:758-765. DOI: 10.1016/j.conbuildmat.2016.02.106

18. Dananjayan RRT, Kandasamy P, Andimuthu R. Direct mineral carbonation of coal fly ash for $\mathrm{CO}^{2}$ sequestration. Journal of Cleaner Production 2016;112(Pt 5):4173-4182. DOI: 10.1016/j. jclepro.2015.05.145

19. Fernández-Jiménez A, Palomo A. Composition and microstructure of alkali activated fly ash binder: Effect of the activator. Cement and Concrete Research. 2005;35(10):1984-1992. DOI: 10.1016/j. cemconres.2005.03.003

20. Li X, Ma X, Zhang S, Zheng E. Mechanical Properties and Microstructure of Class C Fly Ash-Based Geopolymer Paste and Mortar. Materials (Basel). 2013;6(4):1485-1495. DOI: $10.3390 /$ ma6041485

21. Azevedo AGS, Strecker K, de Araújo Jr. AG, da Silva CA. Produção de geopolímeros à base de cinza volante usando soluções ativadoras com diferentes composições de $\mathrm{Na} 2 \mathrm{O}$ e Na2SiO3. Cerâmica. 2017;63(366):143-151. DOI: 10.1590/036669132017633662078

22. Provis JL, van Deventer, JSJ, eds. Geopolymers. Structures, Processing, Properties and Industrial Applications. Cambridge: Woodhead Publishing; 2009. DOI: 10.1533/9781845696382

23. ASTM International. ASTM C 618-12 - Standard Specification for Coal Fly Ash and Raw or Calcined Natural Pozzolan for Use in Concrete. West Conshohocken: ASTM International; 2012.

24. International Organization for Standardization (ISO). ISO 10545-3 (EN) - Ceramic Tiles - Part 3: Determination of water absorption, apparent porosity, apparent relative density and bulk density. Geneva: ISO; 1998.

25. He J, Jie Y, Zhang J, Yu Y, Zhang G. Synthesis and characterization of red mud and rice husk ash-based geopolymer composites. Cement and Concrete Composites. 2013;37:108-118. DOI: 10.1016/j.cemconcomp.2012.11.010

26. Azevedo AGS, Strecker K. Brazilian fly ash based inorganic polymers production using different alkali activator solutions.
Ceramics International. 2017:43(12):9012-9018. DOI: 10.1016/j. ceramint.2017.04.044

27. Atis CD, Görür EB, Karahan O, Bilim C, Ilkentapar S, Luga E. Very high strength $(120 \mathrm{MPa})$ class $\mathrm{F}$ fly ash geopolymer mortar activated at different $\mathrm{NaOH}$ amount, heat curing temperature and heat curing duration. Construction and Building Materials. 2015;96:673-678. DOI: 10.1016/j.conbuildmat.2015.08.089

28. Guo X, Shi H, Dick WA. Compressive strength and microstructural characteristics of class $\mathrm{C}$ fly ash geopolymer. Cement and Concrete Composites. 2010;32(2):142-147. DOI: 10.1016/j. cemconcomp.2009.11.003

29. Criado M, Fernandez-Jimenez A, de la Torre AG, Aranda MAG, Palomo A. An XRD study of the effect of the $\mathrm{SiO} 2 / \mathrm{Na} 2 \mathrm{O}$ ratio on the alkali activation of fly ash. Cement and Concrete Research . 2007;37(5):671-679. DOI: 10.1016/j.cemconres.2007.01.013

30. Panias D, Giannopoulou IP, Perraki T. Effect of synthesis parameters on the mechanical properties of fly ash-based geopolymers. Colloids and Surfaces A: Physicochemical and Engineering Aspects. 2007;301(1-3):246-254. DOI: 10.1016/j. colsurfa.2006.12.064

31. Palomo A, Grutzeck MW, Blanco MT. Alkali-activated fly ashes: A cement for the future. Cement and Concrete Research. 1999;29(8):1323-1329. DOI: 10.1016/S0008-8846(98)00243-9

32. Torres-Carrasco M, Puertas P. Waste glass in the geopolymer preparation. Mechanical and microstructural characterisation. Journal of Cleaner Production. 2015;90:397-408. DOI: 10.1016/j. jclepro.2014.11.074

33. Hounsi AD, Lecomte-Nana GL, Djétéli G, Blanchart P. Kaolinbased geopolymers: Effect of mechanical activation and curing process. Construction and Building Materials. 2013;42:105-113. DOI: 10.1016/j.conbuildmat.2012.12.069

34. Mozgawa W, Deja J. Spectroscopic studies of alkaline activated slag geopolymers. Journal of Molecular Structure. 2009;924926:434-441. DOI: 10.1016/j.molstruc.2008.12.026

35. Temuujin J, Minjigmaa A, Davaabal B, Bayarzul U, Ankhtuya A, Jadambaa T, et al. Utilization of radioactive high-calcium Mongolian flyash for the preparation of alkali-activated geopolymers for safe use as construction materials. Ceramics International. 2014;40(10 Pt B):16475-16483. DOI: 10.1016/j. ceramint.2014.07.157

36. Hela R, Orsáková D. The Mechanical Activation of Fly Ash. Procedia Engineering. 2013;65:87-93. DOI: 10.1016/j. proeng.2013.09.016

37. Pinto AT. Introdução ao Estudo dos Geopolímeros. Vila Real: Universidade Trás-os-Montes e Alto Douro; 2006. Available from: http://www.geopolimero.com.br/PDF/introducao.pdf

38. Cai GB, Chen SF, Liu L, Jiang J, Yao HB, Xu AW, et al. 1,3-Diamino-2-hydroxypropane- $N, N, N^{\prime}, N^{\prime}$-tetraacetic acid stabilized amorphous calcium carbonate: nucleation, transformation and crystal growth. CrystEngComm. 2010;12(1):234-241. DOI: 10.1039/B911426M 